\title{
Dopamine Enhances Glutamate-Activated Currents in Spinal Motoneurons
}

\author{
Dean O. Smith, ${ }^{1}$ Deborah Lowe, ${ }^{1,2}$ Roselynn Temkin, ${ }^{1,2}$ Penny Jensen, ${ }^{1}$ and Hanns Hatt ${ }^{3}$ \\ ${ }^{1}$ Department of Physiology and ${ }^{2}$ Neurosciences Training Program, University of Wisconsin, Madison, Wisconsin \\ 53706, and ${ }^{3}$ Physiologisches Institut der Technischen Universität München, 80802 München, Germany
}

In cultured embryonic chick motoneurons, glutamate-activated currents rise quickly and then decay rapidly to relatively small steady-state current levels. Dopaminergic modulation of these receptors was studied using patch-clamp recording techniques. At concentrations $\geq 10 \mathrm{~nm}$, dopamine enhanced glutamate-activated currents by about $200 \%$. This enhancement was diminished by the nonspecific dopamine receptor antagonist $S(+)$-apomorphine and the more specific $D_{1}$ receptor antagonist $\mathrm{SCH} 23390$, and it was mimicked by the $D_{1}$ partial agonist SKF38393. Glutamate receptor desensitization rate was not altered in the presence of dopamine. Enhancement was specific to the kainate component. Current-variance analysis indicated that in the presence of dopamine the conductances of glutamateactivated channels were not altered but that the relative fraction of kainate-type channels activated by glutamate increased. Intracellular CAMP levels increased by $33 \%$ following exposure to $100 \mu \mathrm{M}$ dopamine. The effects of elevated CAMP or protein kinase $A$ (PKA) were tested by including $100 \mu \mathrm{M}$ CAMP or PKA, respectively, in the recording pipette solution. This increased the kainate-activated currents specifically. Dopaminergic enhancement was not observed when a PKA inhibitor was in the pipette. mRNA encoding $D_{1}$ was detected in the spinal cord by a reverse transcription, polymerase chain-reaction amplification procedure. Thus, dopamine is acting most probably on an avian homolog of the $D_{1}$ receptor family. We conclude that dopamine causes cAMP to increase, which results in increased activation of kainate-gated channels during glutamate-mediated transmission.

[Key words: dopamine, glutamate, kainate, motoneurons, modulation, $\mathbf{C A M P ]}$

Neuronal excitability can be regulated for prolonged periods of time by synaptic modulation. Often, this entails activation by one neurotransmitter of a second-messenger system that alters membrane currents through channels gated by a different, mediating neurotransmitter (Bourne and Nicoll, 1993). For exam-

Received June 20, 1994; revised December 5, 1994; accepted Dec. 9, 1994. We thank Drs. Meyer B. Jackson and Larry Trussell for critical perusal of the manuscript. Ms. Birgit Preibisch and Ms. Jan Hamer provided technical assistance. This work was supported by grants from the National Institutes of Health (NS13600 and GM07507), the Paralyzed Veterans of America Spinal Cord Research Foundation, and the Deutsche Forschungsgemeinschaft (SFB 220).

Correspondence should be addressed to Dean O. Smith, Department of Physiology, University of Wisconsin, 1300 University Avenue, Madison, WI 53706.

Copyright (C) 1995 Society for Neuroscience $0270-6474 / 95 / 153905-08 \$ 05.00 / 0$ ple, when applied to cultured hippocampal neurons, histamine causes currents activated by $N$-methyl-D-aspartate (NMDA) to increase nearly 10-fold (Bckkers, 1993). Although the modulatory transmitter, histamine, is ineffective by itself, it enhances current flow through the NMDA receptors, thus regulating synaptic transmission.

Dopamine is a widespread modulator of glutamate receptors. In perch retinal horizontal cells, exposure to dopamine enhances glutamate-activated currents by increasing the open probability of the kainate-receptor channel (Knapp et al., 1990) and abolishes rapid glutamate receptor desensitization (Schmidt et al., 1994). Likewise, dopamine enhances glutamate-mediated postsynaptic potentials in goldfish Mauthner cells (Pereda et al., 1992, 1994). In contrast, glutamate-activated responses in the mammalian neostriatum are attenuated by dopamine, although the NMDA component is potentiated (Cepeda et al., 1993). Thus, dopamine may have mixed effects on the same neostriatal target neurons.

In spinal motoneurons, dopamine may also have mixed effects. The spinal cord receives dopaminergic innervation (Ridet et al., 1992; Weil-Fugazza and Godefroy, 1993) that facilitates locomotor network activity (Jankowska et al., 1967). Although this appears not to involve direct modulation of motoneuron receptors (Andén et al., 1966), dopamine application increases field potentials recorded from antidromically activated motoneurons (Barasi and Roberts, 1977). In contrast, monosynaptic transmission evoked by dorsal root stimulation and monitored via ventral root compound action potentials was depressed by dopamine agonists (Carp and Anderson, 1982). Thus, the exact nature of dopaminergic modulation of motoneuronal excitability remains somewhat unclear.

In this study, we have used patch-clamp recording techniques to assess dopaminergic modulation of glutamate receptors in motoneurons. Dopamine enhanced kainate receptors specifically, and this involved a $\mathrm{c} \Lambda \mathrm{MP}$-dependent pathway. We conclude that dopamine can enhance glutamate-activated channels in motoneurons.

\section{Materials and Methods}

Neuron preparation. Neurons were prepared using techniques described in detail in Rosenheimer and Smith (1990). Lumbar spinal cords from $6.5 \mathrm{~d}$ (stage 28) embryonic chicks were dissected, freed of their meninges and dorsal root ganglia, and collected in ice-cold buffer. Following incubation at $37^{\circ}$ with $0.05 \%$ trypsin and $0.005 \%$ DNase I, the cells were dissociated by gentle trituration. Motoneuron-enriched cell fractions were then generated on the basis of their buoyant density in a metrizamide solution (Schnaar and Schaffner, 1981). The effectiveness of this procedure for enrichment of motoneurons was verified by labeling the motoneurons via cut ventral roots with the fluorescent dye rho- 
damine prior to dissociation. Approximately $92 \%$ of the recovered cells contained the fluorescent label and were identified specifically as motoneurons (Rosenheimer and Smith, 1990).

After isolation, the motoneurons were incubated in Dulbecco's modified Eagle medium (DME; GIBCO) plus 10\% horse serum (Sigma) at $37^{\circ}$ with $5 \% \mathrm{CO}_{2}$. Recordings were obtained from cells maintained between 1 and $2 \mathrm{~d}$ in culture.

Electrophysiological recordings. Membrane currents were recorded using patch-clamp techniques at room temperature in whole-cell and outside-out configuration. Ihroughout the recording experiments, the neurons were bathed with continuously flowing $(6 \mathrm{ml} / \mathrm{min})$ buffer (the "bath solution") containing (mM) $\mathrm{NaCl}(140), \mathrm{KCl}(5.3), \mathrm{CaCl}_{2}$ (2), $\mathrm{Na}_{2} \mathrm{HPO}_{4}(0.67), \mathrm{KH}_{2} \mathrm{PO}_{4}(0.22)$, HEPES (15), and glucose (5.6); $\mathrm{pH}=$ 7.4. Agonists were dissolved in this extracellular saline. The pipette solution contained (mM) $\mathrm{KCl}$ (140), $\mathrm{CaCl}_{2}$ (1), $\mathrm{MgCl}_{2}$ (2), FGTA (11), glucose (10), ATP (0.1), GTP (0.1), and HEPES (10; pH = 7.2). The currents were amplified (List EPC7 and Axopatch 200A) and stored on vidco tapc for subsequent evaluation. Records were filtered at $2-4 \mathrm{kHz}$ and digitized at $10-50 \mathrm{kHz}$. Resting membrane potentials were generally between -45 and $-60 \mathrm{mV}$.

Agonist application. To achieve rapid application of glutamate agonists to the electrode tip, a liquid-filament system was used (Dudel et al., 1990). A polyethylene tube drawn to a $30 \mu \mathrm{m}$ tip diameter was fixed in the bath parallel to the direction of flow of the bath solution. The ligand-containing solution was ejected under pressure $(1 \mathrm{atu})$ from this tube as a thin $(30 \mu \mathrm{m})$ stream. The tube was connected to a piezo crystal. On voltage application to the piezo, the tube shifted upward 20 $\mu \mathrm{m}$ within about $200 \mu \mathrm{sec}$. With this system, the ligand was introduced to the electrode tip at a constantly maintained concentration at a speed sufficient to result in receptor activation within $<20 \mathrm{msec}$ in whole-cell recording configuration. On cessation of the voltage pulse, the ligandcontaining solution was moved rapidly away from the electrode tip, again exposing the tip to normal bath solution. Two reservoirs, arranged in parallel, supplied the bath solution-one with and one without dopamine; a manually operated valve enabled us to switch from one reservoir to the other. Thus, the cell or membrane patch was bathed continuously in a extracellular bath saline solution with or without dopamine except during the brief, piezo-activated excursion into the glutamate agonist-containing liquid filament.

CAMP assay. After isolation on the metrizamide gradient, the motoneurons were divided into four to six reaction tubes containing extracellular recording buffer and allowed to equilibrate on ice for $30 \mathrm{~min}$. Each reaction contained between 8 and $13 \mathrm{mg}$ wet weight of tissue. Dopamine $(1-1000 \mu \mathrm{M})$ or forskolin $(100 \mu \mathrm{M})$ was then added to the appropriate tube. After $30 \mathrm{~min}$, the reactions were stopped and cAMP was extracted by pelleting the cells at $4^{\circ}$ and resuspending them in cold $10 \%$ trichloroacetic acid. After a 20 min incubation on ice, the trichloroacetic acid was removed with water-saturated ether. The samples were lyophilized and stored at $-20^{\circ}$.

cAMP levels were then assayed using a commercial enzyme-immunoassay system (Amersham, UK). The acetylation method described by the manufacturer was used without modification. Results were standardized to calculated protein content.

$m R N A$ detection. Poly $\mathrm{A}^{+} \mathrm{RNA}$ was extracted from isolated spinal cord using a commercial kit (Micro-FastTrack, Invitrogen, San Diego, $\mathrm{CA}$ ) without modification. The mRNA was then reverse-transcribed and amplified in a polymerase chain reaction (RT-PCR, Perkin Elmer) using primers specific to the nucleotide sequence encoding the rat $D_{1}$ receptor (Zhou et al., 1990). The primer sequences were 5'-GACGTGTTTGTGTGGTTTGGG-3' and 5'-GGATCTTTTCTAGAGAGACAT-3'. The amplified products were visualized on a $1.2 \%$ agarose gel. As positive controls, cDNA clones of $D_{1}$ kindly provided by $D$. $K$. Grandby (Zhou et al., 1990) served as templates in PCR reactions using the same primers. To confirm the identity of PCR-amplified products, gels were analyzed by Southern blots using $\alpha-{ }^{32} \mathrm{P}-\mathrm{CTP}-$ labeled RNA transcripts from the cDNA clones.

Statistics. All statistical measures are presented \pm standard error. Computed standard errors of ratios of variables were determined using methods described in Kendail and Stuart (1969). Regression analyses and comparisons of variance used standard $F$-tests, and comparisons of means used $t$ tests. All statistical tests were two sided. Curve-fitting routines were performed using ORIGIN software (MicroCal Software, Inc.).

Chemicals. Most organic compounds were obtained from Sigma (St. Louis). However, CNQX was purchased from Tocris Neuroamin (Cambridge), and $S(+)$-apomorphine, SCH23390, and SKF38393 were pur- chased from Research Biochemicals Incorporated (Wayland, MA). Further exceptions are noted in context.

\section{Results}

\section{Dopamine enhances glutamate-activated currents}

In whole-cell recordings, dopamine enhanced glutamate-activated currents (Fig. 1). Although dopamine alone did not alter membrane current, exposure of the motoneurons to dopamine at concentrations as low as $10 \mathrm{nM}$ was sufficient to increase glutamate-activated currents. Higher dopamine concentrations $(>10$ nM) caused greater increases, but concentrations from 1 to 1000 $\mu \mathrm{M}$ were equally effective, indicating saturation at $\leq 1 \mu \mathrm{M}$. Enhancement occurred within $1 \mathrm{~min}$ after dopamine application. Following removal of dopamine, the effect declined progressively; after about $10 \mathrm{~min}$, it was no longer evident. Therefore, we routinely maintained dopamine in the bath while recording its effects. Currents were analyzed quantitatively in 19 neurons. At saturating concentrations $(\geq 1 \mu \mathrm{M})$, dopamine caused peak and steady-state current amplitudes to increase by $142( \pm 18)$ and $299( \pm 47) \%$, respectively (Fig. 1C); both changes are significant statistically $(p<0.05)$. In similar experiments $(n=3)$, another potential modulator, serotonin $(100 \mu \mathrm{M})$, was added to the bath, but it had no effect.

Glutamate-activated currents rise quickly and then decay rap idly to relatively small steady-state current levels (Fig. 1). To determine whether this rapid desensitization is affected by dopamine (cf. Schmidt et al., 1994), a double exponential function was fit to the decay phase from peak to steady-state current amplitudes, and the time constants, $\tau_{1}$ and $\tau_{2}$, were estimated. Following $\geq 1 \mathrm{~min}$ of continuous exposure to dopamine (100 $\mu \mathrm{M})$, there was an insignificant $(0.05$ level) difference in either decay rate $\left(\tau_{1}\right.$ and $\left.\tau_{2}\right)$ before and after exposure to dopamine; the average values for $\tau_{1}$ were $17( \pm 2)$ and $18( \pm 4) \mathrm{msec}$, respectively $(n=19)$, and the corresponding values for $\tau_{2}$ were $112( \pm 20)$ and $176( \pm 26) \mathrm{msec}$. Consequently, dopamine does not alter glutamate receptor desensitization rate in these motoneurons.

Enhancement was specific to the kainate component of the glutamate-activated currents (Fig. 2A), which increased by 197 $( \pm 27) \%(n=9 ; p<0.05)$. Neither AMPA- nor NMDA-evoked currents were affected by the presence of dopamine (Fig. $2 A ; n$ $>6$ for each group). The dopamine-augmented currents were reduced considerably by the non-NMDA receptor antagonist CNQX (10 $\mu \mathrm{M}$; Fig. $2 B$ ). Residual glutamate-activated current was blocked fully by further addition of the NMDA receptor antagonist APV $(10 \mu \mathrm{M})$. This indicates that the enhanced current can be blocked completely by glutamate receptor antagonists and is, therefore, glutamate-gated.

The dopamine receptor subtype was tested pharmacologically (Fig. 3). The $D_{1}$ partial agonist SFK38393 (10 $\left.\mu \mathrm{M}\right)$ mimicked the effects of dopamine; the peak amplitude of glutamate-activated $(1 \mathrm{mM})$ currents increased by $139( \pm 9) \%(n=3 ; p<$ 0.05 ; Fiy. $3 A$ ). Dopaminergic enhancement was diminished by the nonspecific dopamine receptor antagonist $S(+)$-apomorphine; the enhanced currents were reduced by $37( \pm 5) \%(n=$ $6 ; p<0.05)$ in the presence of $10 \mu \mathrm{M} S(+)$-apomorphine (Fig. $3 B)$. SCH23390 $(10 \mu \mathrm{M})$, a more specific antagonist of the $D_{1}$ dopamine receptor classes, also reduced the enhanced current by $42( \pm 6) \%(n=9 ; p<0.05$; Fig. $3 C)$. These results indicate that dopamine is acting most probably on the $D_{1}$ or the $D_{5}$ receptor class.

Since dopamine, via the $D_{1}$ receptor family and a $G_{s}$ protein, 


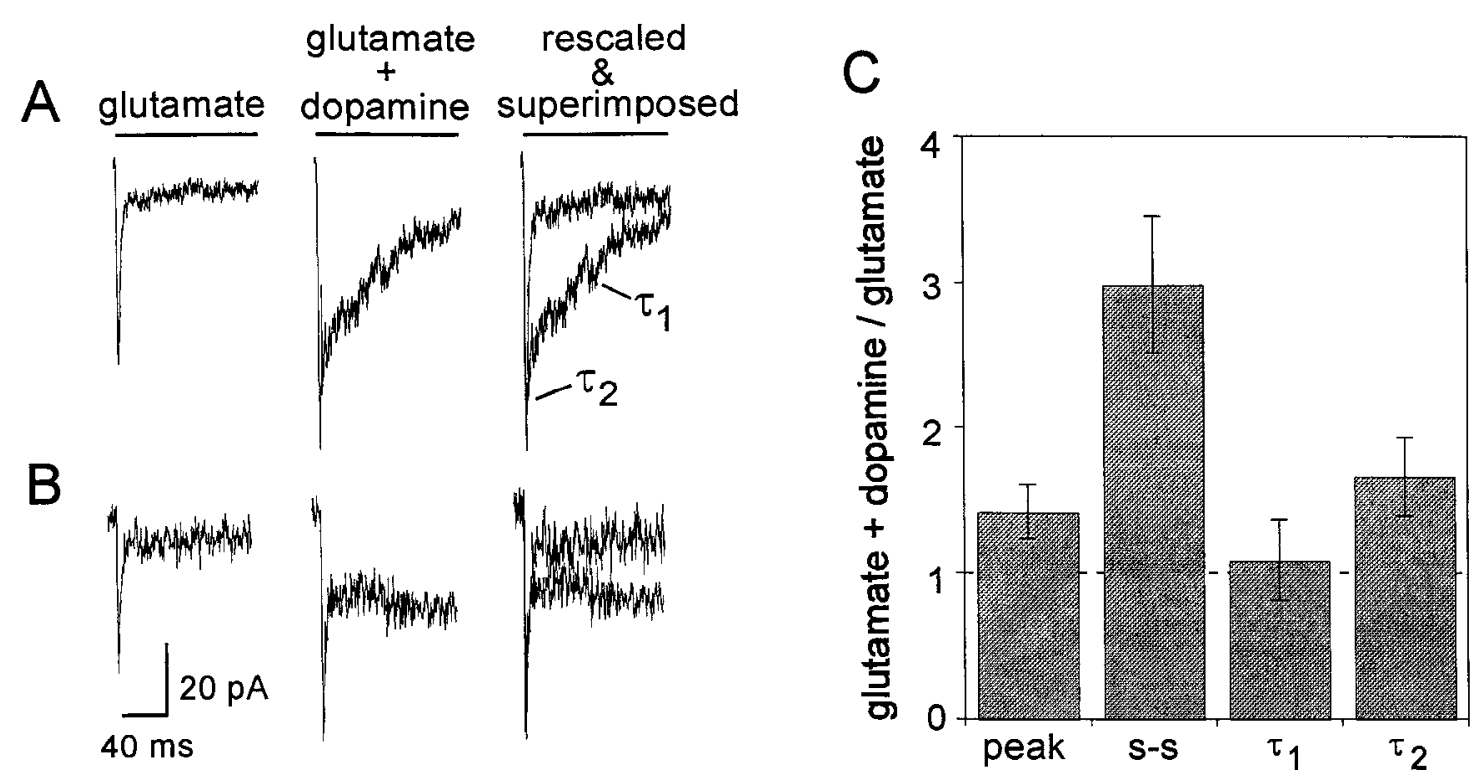

Figure 1. Dopamine enhances glutamate-activated currents. The duration of agonist application is shown by the bar above each column. Wholecell recordings from two different neurons are shown $(A$ and $B$ ) before and after $(\geq 1 \mathrm{~min})$ addition of $100 \mu \mathrm{M}$ dopamine to the bath; dopamine was maintained in the bath for the duration of the recording. Records obtained before and after dopamine addition were scaled to equal peak amplitudes and superimposed to compare desensitization rates and steady state current values. $A$, In neurons analyzed shortly after exposure to dopamine (within 1-2 min; $1 \mathrm{~min}$ in this record), responses similar to those shown were seen $(n=10)$; after an initial rapid decay, exposure to dopamine caused a slow current decay from peak to enhanced steady-state levels. Holding potential was $-35 \mathrm{mV}$. $B$, After longer exposure to dopamine (longer than about $2 \mathrm{~min} ; 5 \mathrm{~min}$ in this record), responses were generally similar to those shown $(n=9$ ); the rapid decay was followed by a relatively stationary steady-state current level, which was enhanced by dopamine. Holding potential was $-25 \mathrm{mV}$. $C$, The effects of dopamine $(100 \mu \mathrm{M})$ on peak (peak) and steady-state $(s-s)$ glutamate-activated currents are summarized $(n=19) . \tau_{1}$ and $\tau_{2}$ refer to the desensitization time constants estimated by fitting a double exponential curve to the decay phase from peak to steady-state values.

activates adenylate cyclase (Kebabian and Greengard, 1971), cAMP and therefore protein kinase A may be involved. Consistent with a second-messenger pathway, dopamine had no effect on currents recorded from excised membrane patches in outsideout configuration (Fig. 4A). With GTP in the pipette (normally included in the recording pipette to minimize "run down"), repeated or continuous application of dopamine caused enhancement for up to about $40 \mathrm{~min}$ (our longest recording from one cell; Fig. 4B). However, when GTP was omitted, enhancement in the continued presence of dopamine became progressively less over a period of about 15-20 min (Fig. 4C). This is consistent with a GTP-dependent second-messenger pathway.
The role of protein kinase $\mathrm{A}$ was tested by including a protein kinase A inhibitor, PKI-(6-22)-amide (10 $\mu \mathrm{M}$; Glass et al., 1989), in the recording pipette. Under these conditions, dopamine did not enhance glutamate-activated currents; peak amplitudes in the presence of dopamine were $93( \pm 12 ; n=5) \%$ of the corresponding values recorded prior to dopamine exposure. Thus, protein kinase A may be involved in the enhancement.

\section{Dopamine causes cAMP levels to increase}

To determine whether dopamine causes motoneuron cAMP levels to change, cAMP was measured before and 30 min after addition of dopamine to the bathing solution (Fig. 5A). Follow-

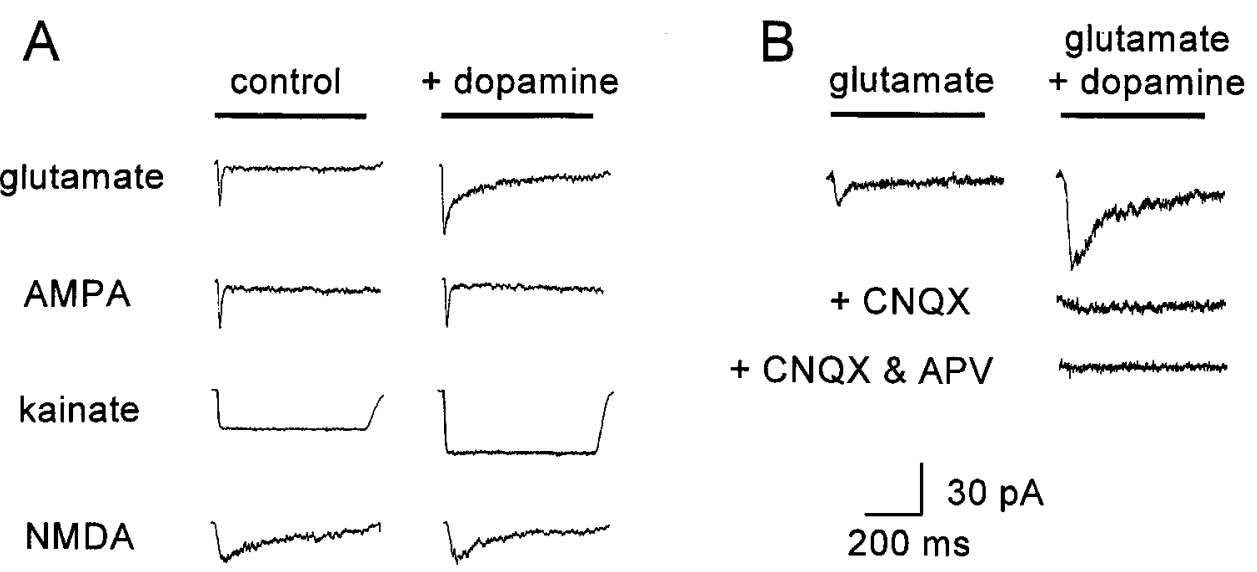

Figure 2. Specificity of dopaminergic enhancement. The duration of agonist application is shown by the bar above each column. A, Whole-cell recordings from one neuron of agonist-activated responses before (control) and after addition of $100 \mu \mathrm{M}$ dopamine $(+$ dopamine) to the bath. Holding potential was $-40 \mathrm{mV}$. $B$, Dopamine enhanced a glutamate-gated current specifically. In whole-cell configuration, glutamate (1 $\mathrm{mm}$ ) activated a characteristic current (glutamate) that was enhanced following exposure to $100 \mu \mathrm{M}$ dopamine in the bath for $5 \mathrm{~min}$. Addition of CNQX $(10 \mu \mathrm{M})$ inhibited the current ( $+C N Q X)$, and further addition of APV $(10 \mu \mathrm{M})$ blocked the current $(+$ $C N Q X \& A P V$ ). Dopamine remained in the bath throughout these experiments. Holding potential was $-25 \mathrm{mV}$. 
Figure 3. Dopamine probably acts via the $\mathrm{D}_{1}$ receptor. $A$, Glutamate (1 mM) activated a whole-cell current (glutamate) that was enhanced following addition of the $\mathrm{D}_{1}$ partial agonist SKF38393 $(10 \mu \mathrm{M})$. Holding potential was $-30 \mathrm{mV}$. B. Addition of $100 \mu \mathrm{M}$ dopamine $(+$ dopamine $)$ caused enhancement, but further addition of 10 $\mu \mathrm{M} S(+)$-apomorphine (+ $S(+)$-apomorphine) reduced the effect. Holding potential was $-40 \mathrm{mV}$. $C$, Likewise, addition of the more specitic $D_{1}$ (and $\mathrm{D}_{5}$ ) antagonist $\mathrm{SCH} 23390(10 \mu \mathrm{M})$ reduced enhancement. Holding potential was $-40 \mathrm{mV}$. The calibrations in $B$ and $C$ are the same.
A

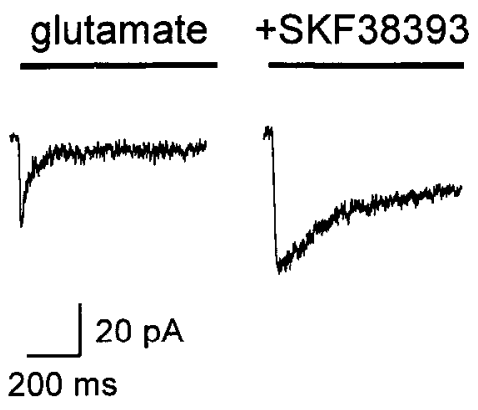

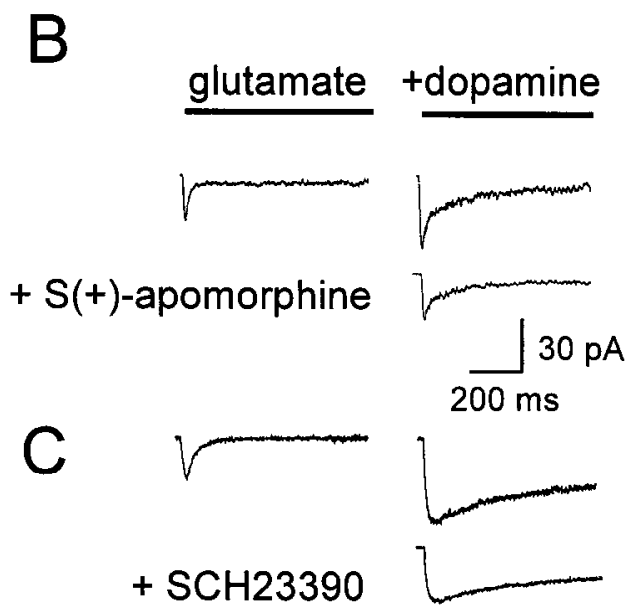

ing addition of dopamine, cAMP levels increased in a dosedependent fashion. At $1 \mu \mathrm{M}$ dopamine, cAMP increased by $18 \%$; at $100 \mu \mathrm{M}$ dopamine, cAMP rose by $33 \%$, from $4.5( \pm 0.3)$ to $6.0( \pm 0.6) \mathrm{pmol} / \mathrm{mg}$ protein $(n=10, p<0.05)$. The results of $1 \mu \mathrm{M}$ dopamine were not significant statistically, probably because only a fraction of the adenylate cyclase pool was activated. For comparison, $10 \mu \mathrm{M}$ forskolin, which activates adenylate cyclase directly, caused cAMP levels to increase to 13.44 $( \pm 1.36 ; n=10) \mathrm{pmol} / \mathrm{mg}$ protein under the same conditions. By inference, saturating concentrations of dopamine $(100 \mu \mathrm{M})$ thus activated via a G-protein an adenylate cyclase pool that is $45 \%$ as large as the forskolin-sensitive pool. In a related context, $1 \mu \mathrm{M}$ dopamine produces maximal enhancement but submaximal cAMP elevation. Some step "downstream" from cAMP production may therefore limit dopaminergic modulation of the glutamate receptors.

\section{cAMP causes glutamate-and kainate-activated currents to increase}

The effects of elevated intracellular cAMP on glutamate-activated currents were also tested and compared with those following exposure to dopamine. Intracellular cAMP levels were increased by adding $100 \mu \mathrm{M}$ cAMP to the recording pipette solution. Pcak and stcady-statc currents activatcd by application of $1 \mathrm{mM}$ glutamate were measured in 31 neurons with cAMP in the pipette and were compared with similar values obtained from 28 other neurons without cAMP in the pipette. Likewise, the current decay phase, from peak to steady-state level, was fit by a double exponential curve, and the time constants $\tau_{1}$ and $\tau_{2}$ were estimated.

cAMP in the recording pipette enhanced peak and steady-state current amplitudes by $166( \pm 25)$ and $230( \pm 40) \%$, respectively, but had no effect on either component $\left(\tau_{1}\right.$ and $\left.\tau_{2}\right)$ of the
A

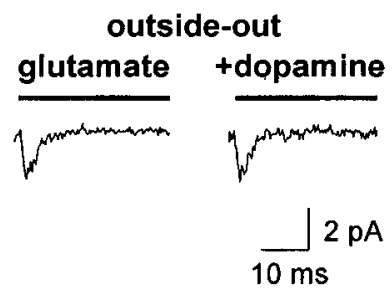

C

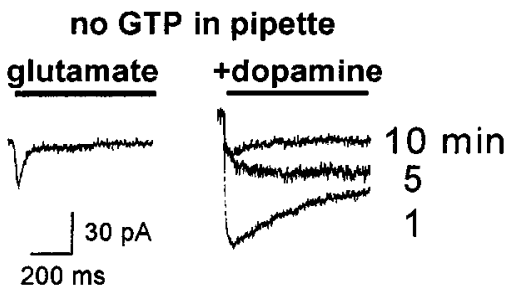

B

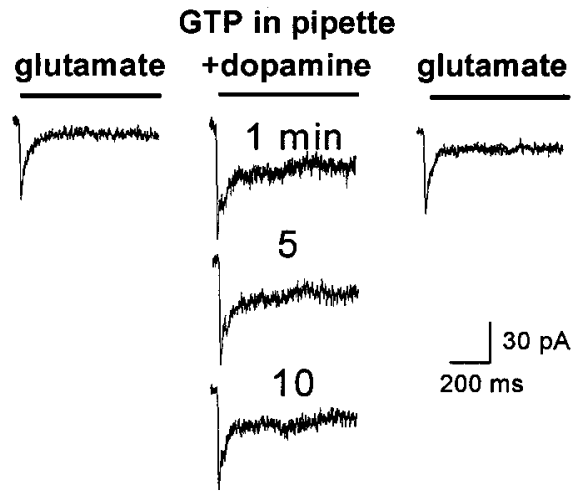

Figure 4. A G'IP-coupled second-messenger pathway is probably activated by dopamine. A, Outside-out patch recordings of glutamate-activated $(1 \mathrm{mM})$ currents before and after addition of $100 \mu \mathrm{M}$ dopamine to the bath. Dopamine had no effect. Holding potential was $-60 \mathrm{mV}$. $B$, In wholecell configuration with $100 \mu \mathrm{M}$ GTP in the recording pipette, a glutamate $(100 \mu \mathrm{M})$-activated current was recorded. Dopamine (100 $\mu \mathrm{M})$ was then added to the bath $(+$ dopamine), and recordings were obtained after 1,5 , and 10 min. Enhancement persisted for at least 10 min. Dopamine was then washed out, and after a 5 min pause, glutamate was applied (right-hand column). There was no enhancement, indicating that the dopaminergic effect was reversible. Holding potential was $-35 \mathrm{mV}$. $C$, GTP was omitted from the pipette solution in whole-cell recordings of glutamate (100 $\mu \mathrm{M}$ )-activated currents before and 1,5 , and $10 \mathrm{~min}$ after exposure to $100 \mu \mathrm{M}$ dopamine. Enhancement became progressively less and was not evident after $15 \mathrm{~min}$. Holding potential was $-40 \mathrm{mV}$. 
A

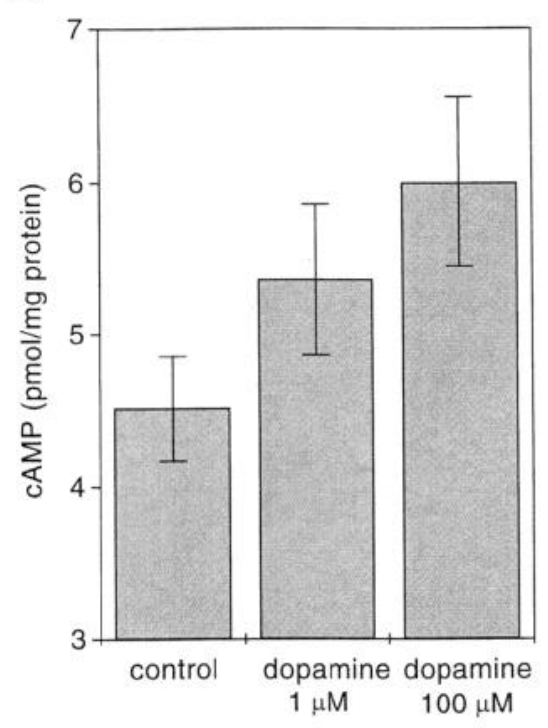

B

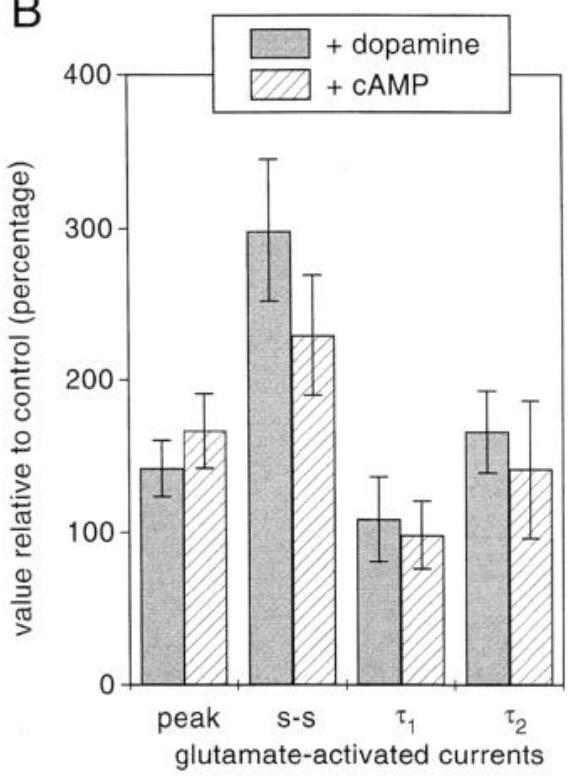

Figure 5. cAMP mediates enhancement by dopamine. $A$, Motoneuron cAMP levels were assayed before (control ) and after addition of dopamine to the bath for $30 \mathrm{~min}$ at room temperature. The averages ( \pm standard error) of 10 different assays are shown. $B$, Increased cAMP results in larger peak and steady-state current amplitudes. Intracellular cAMP levels were increased by including $100 \mu \mathrm{M}$ cAMP in the recording pipette. Whole-cell glutamateactivated $(1 \mathrm{~mm})$ currents recorded with cAMP in the pipette $(n=31)$ were then compared to control recordings obtained without $\mathrm{cAMP}$ in the pipette $(n=28)$. The average ( \pm standard error) ratios of these values are shown (hatched bars). $\tau_{1}$ and $\tau_{2}$ refer to the decay time constants estimated by fitting a double exponential curve to the decay phase from peak to steadystate values. For comparison, the relative enhancement of glutamate-activated currents following exposure to 100 $\mu \mathrm{M}$ dopamine are also shown $(n=19$; filled bars). current decay (Fig. 5B). These changes are comparable quantitatively to those produced by exposure to dopamine (Fig. $5 B$ ). Furthermore, enhancement due to inclusion of cAMP in the pipette were specific to the kainate component. Kainate-activated currents increased by $160( \pm 16) \%$ (control, $n=9$; with cAMP, $n=6$ ). In contrast, responses to AMPA and to NMDA were unaffected ( $n>6$ for each group). In recordings from eight additional neurons, protein kinase A $(100 \mu \mathrm{lof} 1 \mathrm{mg} / \mathrm{ml})$ was added to the pipette instead of cAMP. Similar results were obtained; peak and steady-state glutamate-activated current amplitudes were $172( \pm 30) \%$ and $204( \pm 22) \%$, respectively, larger than those recorded without protein kinase $\mathrm{A}$ in the pipette. By inference, cAMP enhances the kainate component of glutamateactivated currents via protein kinase $\mathrm{A}$.

\section{Dopamine increases the kainate component of glutamate- activated currents}

Enhanced kainate-activated current amplitudes could be due to increased channel conductance. Current-variance analysis (Stevens, 1972) was used to test this possibility (cf. Knapp et al., $1990)$. For a population of $N$ channels, $\sigma^{2}=\mu i-\left(\mu^{2} / N\right)$, where $\sigma^{2}$ is the current variance, $\mu$ is the average current, and $i$ is the single-channel current. If $\mu$ is small, this simplifies to $\sigma^{2}=\mu i$, and the ratio $\sigma^{2} / \mu$ (determined by calculating the slope of a plot of the data) divided by the membrane holding potential provides an estimate of the apparent channel conductance, $\gamma$. Glutamate, kainate, AMPA, and NMDA were applied, and average steadystate current and variance were measured in neurons before and after exposure to dopamine $(100 \mu \mathrm{M})$. To attain stationary records with small values of $\mu$, steady-state glutamate (1 mM), AMPA ( $1 \mathrm{~mm}$ ), and NMDA ( $1 \mathrm{~mm}$ plus $1 \mu \mathrm{M}$ glycine)-activated currents were measured after desensitization had occurred; nondesensitizing kainate-gated $(10 \mu \mathrm{M})$ currents were measured during steady-state activation. At this stage of development (just before peripheral synapses form), the motoneurons respond uniformly to glutamate and its agonists; there is negligible variability from one cell to another (Smith et al., 1991, personal observations). Therefore, data from numerous neurons were pooled for the analysis.

Dopamine caused a significant reduction in the slope $\left(\sigma^{2} / \mu\right)$ estimated from glutamate-activated currents (Fig. 6A), but it had no effect on the slopes of currents activated by AMPA, kainate, or NMDA (Fig. $6 B-D$ ). Likewise, dopamine reduced the calculated apparent channel conductance of the glutamate but not the AMPA, kainate, or NMDA receptors (Table 1). The glutamate-activated currents include contributions from kainate-, AMPA-, and NMDA-type channels. Consequently, $\sigma^{2} / \mu_{\mathrm{glu}}=$ $\omega_{\text {kainate }} \cdot \sigma^{2} / \mu_{\text {kainate }}+\omega_{\mathrm{AMPA}} \cdot \sigma^{2} / \mu_{\mathrm{AMPA}}+\omega_{\mathrm{NMDA}} \cdot \sigma^{2} / \mu_{\mathrm{NMDA}}$, where $\omega$ represents the fractional contribution of that particular channel type. In the same way, $\gamma_{\text {Glu }}=\omega_{\text {kainate }} \cdot \gamma_{\text {kainate }}+\omega_{\mathrm{AMPA}} \cdot \gamma_{\mathrm{AMPA}}+$ $\omega_{\mathrm{NMDA}} \cdot \gamma_{\mathrm{NMDA}}$. Since neither $\gamma_{\text {kainate }}, \gamma_{\mathrm{AMPA}}$, nor $\gamma_{\mathrm{NMDA}}$ were altered by exposure to dopamine, the decrease in $\gamma_{\mathrm{Glu}}$ may be attributed to changes in the fractional contributions $\omega . \gamma_{\text {kainate }}$ is the only apparent channel conductance that is significantly less than $\gamma_{\mathrm{Glu}}$, so increasing its weight will lower $\gamma_{\mathrm{Gitu}}$. Therefore, the decrease in $\gamma_{\mathrm{Glu}}$ following exposure to dopamine may be assigned to an increase in the kainate-gated component, $\omega_{\text {kainatc* }}$

\section{Dopamine receptor message is transcribed in spinal cord}

To aid in the determination of which dopamine receptor subtypes might underlie the enhancement, mRNA encoding $D_{1}$ was probed using gene-amplification techniques. With primers based on rat D, cDNA sequences (Zhou et al., 1990), chick spinal cord mRNA was amplified using reverse transcriptase-polymerase chain reactions (RT-PCR). An amplification product was obtained, indicating the presence of mRNA encoding $D_{1}$ subtypes in chick spinal cord (Fig. 7).

\section{Discussion}

These results indicate that dopamine causes cAMP levels to increase, and this enhances kainate-activated currents. These changes do not occur when an inhibitor of protein kinase $\mathrm{A}$ is added to the pipette, and they run down within about $15 \mathrm{~min}$ when GTP is omitted from the recording pipette. A tenable con- 
Figure 6. Channel conductances are not affected by dopamine. The average and variance of steady-state currents were measured in whole-cell configuration before (filled circles, solid lines) and after (open circles, dotted lines) exposure to $100 \mu \mathrm{M}$ dopamine $(D A)$ for at least $5 \mathrm{~min} . A-D$, To attain stationary records, steady-state glutamate (1 mM), AMPA ( $1 \mathrm{~mm}$ ), and NMDA ( $1 \mathrm{~mm}$ plus $1 \mu \mathrm{M}$ glycine)-activated currents were measured after desensitization had occurred; nondesensitizing kainate-gated $(10 \mu \mathrm{M})$ currents were measured during steady-state activation. Each point represents data from a different neuron. Currents were recorded at holding potentials, $\mathrm{E}_{\text {ludding, }}$, ranging from -25 to $-60 \mathrm{mV}$; since the current-voltage relationships are linear over this range (Smith et al., 1991), the amplitudes, $A$. were normalized to values expected at $-60 \mathrm{mV}, A_{-60}$, by the formula $A_{-60}=$ $A / E_{\text {lolding }} /-60 \mathrm{pA}$. Straight lines were fit by the method of least squares. The number of points and the slopes for each case are summarized in Table 1.
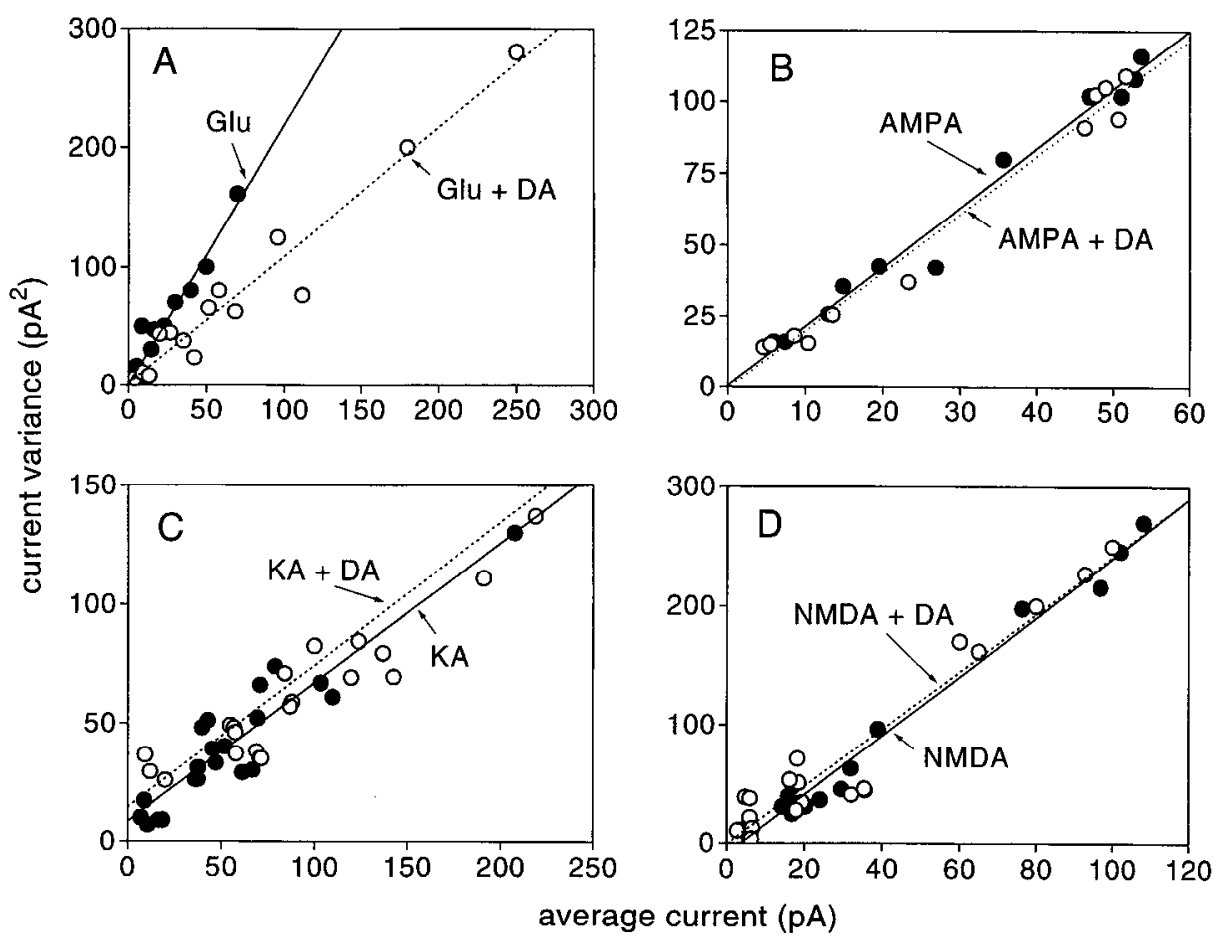

clusion is that dopamine activates a $G_{s}$ protein-coupled pathway, causing increased cAMP levels and protein kinase A activity. Quite probably, kainate receptors are then phosphorylated by protein kinase $\mathrm{A}$, thus increasing channel opening probability and larger kainate-activated currents.

Further evidence substantiates kainate receptor phosphorylation hy cAMP-mediated pathways. In hippocampal neurons, elevated cAMP levels (obtained by application of forskolin) potentiate glutamate-activated currents by increasing the opening frequency and mean open time of non-NMDA-type channels (Greengard et al., 1991). These are probably the kainate-sensitive channels, because bath application of the protein phosphatase inhibitor okadaic acid increases kainate-activated currents and conductance in perforated patch recordings from cultured hippocampal neurons (Wang et al., 1991). Moreover, transiently expressed GluR6, a kainate-activated receptor subtype that is present in embryonic chick motoneurons (Temkin et al., 1993), generates increased currents when phosphorylated via protein kinase A (Raymond et al., 1993; Wang et al., 1993).

Although protein kinase A seems to be involved, alternative consequences of dopaminc application could occur. For cxam-

$\begin{aligned} & \text { Table 1. Single-channel conductances estimated from current- } \\
& \text { variance analyses }\end{aligned}$
\begin{tabular}{lll} 
& Control & + Dopamine \\
\hline Glutamate (14) & $36 \pm 3$ & $18 \pm 1$ \\
AMPA (12) & $31 \pm 5$ & $28 \pm 6$ \\
Kainate (22) & $10 \pm 1$ & $10 \pm 3$ \\
NMDA (19) & $42 \pm 1$ & $40 \pm 3$
\end{tabular}

Agonist concentrations were 0.01-1 mM. Current and variance measurements were obtained after receptor desensitization (except for the kainate receptors), when current levels were stationary. Straight lines were fit by the method of least squares, and the average values \pm standard error of the slopes are presented. The numbers of different neurons from which data were obtained are in parentheses. Units are pS. ple, dopamine acting on the $D_{1}$ receptor may also increase phospholipase C activity (Felder et al., 1989) and inositol trisphosphate production (Mahan et al., 1990). This pathway could change excitability by altering ion conductances. Any alternative events brought about by dopamine, however, must enhance the glutamate-activated currents by acting on the glutamate receptor itself since the enhanced currents were hlocked totally by the combination of CNQX and APV.

As in motoneurons, protein kinase A enhances the kainategated component in retinal horizontal cells, presumably by cAMP-dependent protein phosphorylation (Liman et al., 1989). This is associated with an increased probability of non-NMDA receptor channel opening and glutamate-activated currents (Knapp et al., 1990; cf. Schmidt et al., 1994). Dopamine also enhances electrotonic coupling and glutamatergic transmission onto the goldfish Mauthner cell, and this, too, is blocked by either the $\mathrm{D}_{1}$ inhibitor $\mathrm{SCH} 23390$ or the protein kinase A inhibitor $\mathrm{PKI}_{5-24}$ (Pereda et al., 1994). Thus, the same modulatory pathway occurs in three distinctly different neuronal types in fish and mammals. These effects of dopamine on glutamategated transmission are not unique, however. In the striatum, for example, dopamine increases NMDA-evoked currents but decreases AMPA-activated currents through $D_{1}$ and $D_{2}$ receptors, respectively (Cepeda et al., 1993).

Dopamine is most probably acting on a $\mathrm{D}_{1}$-type receptor. The relatively nonspecific dopamine receptor antagonist $S(+)$-apomorphine and the specific mammalian $\mathrm{D}_{1}$ (and $\mathrm{D}_{5}$ ) antagonist SCH23390 reduced enhancement. Conversely, the D partial agonist SKF38393 mimicked the effect of dopamine. Furthermore, mRNA encoding $D_{1}$ is also present in the spinal cord. In other preparations, the $D_{1}$ and $D_{5}$ families activate adenylate cyclase in vitro (O'Dowd, 1993), and dopamine increases cAMP levels in these motoneurons, consistent with $D_{1}$ receptor activation. Therefore, pharmacological, molecular, and physiological evidence indicates that dopamine is acting through an avian homologue of the $\mathrm{D}_{1}$ (or the related $\mathrm{D}_{5}$ ) receptor subtype. 


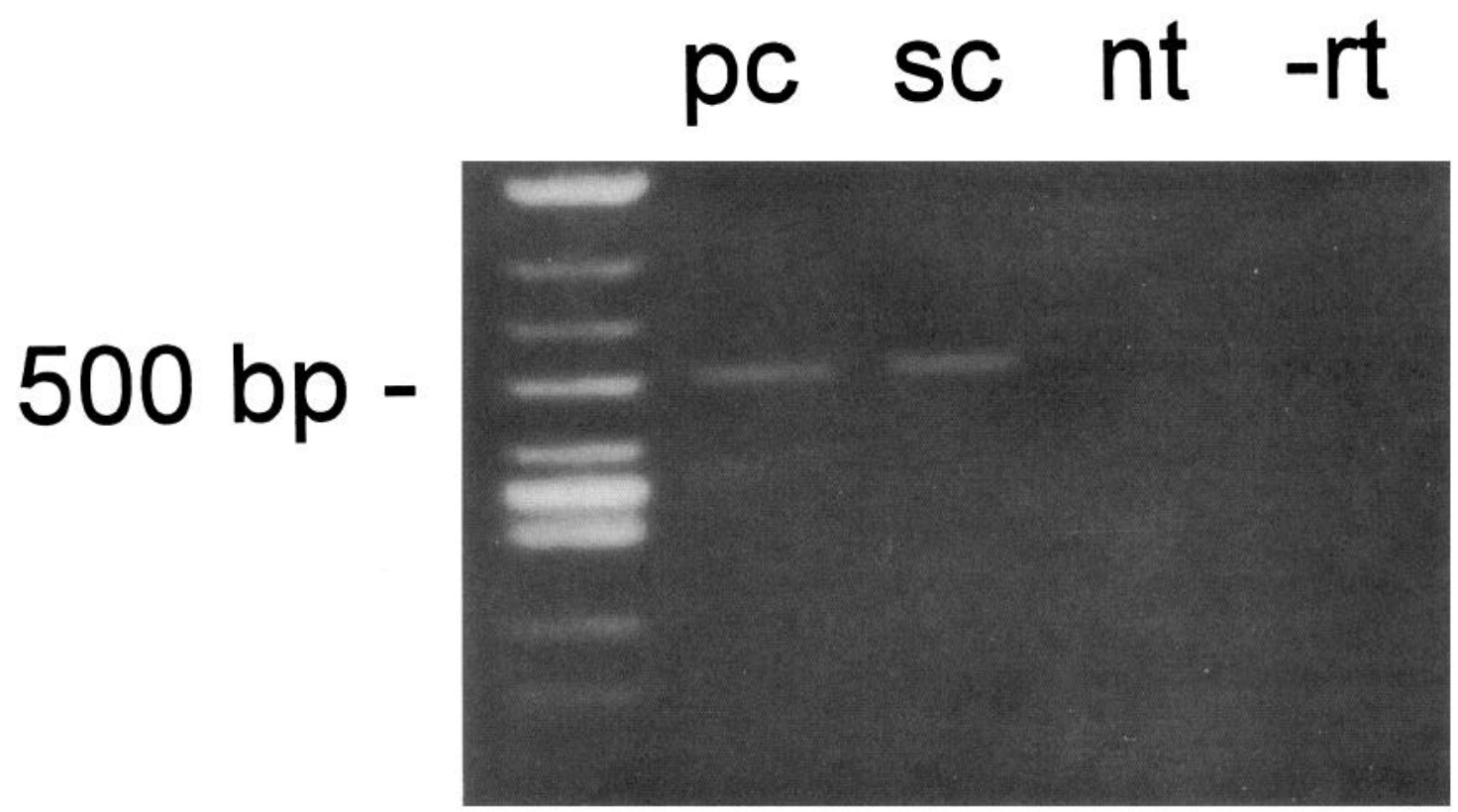

Figure 7. Spinal cord neurons transcribe genes encoding dopamine receptors. mRNA was extracted and amplified by RT-PCR using primers based on the nucleotide sequence of the rat $\mathrm{D}_{1}$ receptor. The left-hand lane is a ladder from a Hinc II digest of $\phi X 174$ (United States Biochemical). The PCR-amplified products from plasmids $(p)$ containing the full-length $\mathrm{D}_{1}$ receptor cDNA clone and from spinal cord $(s c)$ are shown. Control reactions run with no reverse transcriptase $(-r t)$ and no template $(n t)$ are also shown; no amplified products were detected in these control reactions.

From a functional perspective, dopaminergic modulation potentiates motoneuron excitability through the enhanced response to glutamate. This is contrary to evidence suggesting that dopamine depresses monosynaptic transmission from dorsal to ventral root pathways (Carp and Anderson, 1982) or that dopamine has negligible effects directly on the motoneuron (Andén et al., 1966). These divergent effects of dopamine could depend on developmental stage; our results were obtained from early embryonic chicks, but those of Carp and Anderson (1982) and Andén et al. (1966) were from adult cats. Furthermore, mRNA encoding the $\mathrm{D}_{2}$ receptor, is also present in the embryonic motoneurons (Smith and Hatt, 1993; cf. Surmeier et al., 1992). It may not be translated until later in development, which could result in markedly different responses to dopamine.

\section{References}

Andén NE, Jukes MGM, Lundberg A, Vyklicky L (1966) The effect of DOPA on the spinal cord. Acta Physiol Scand 67:373-386.

Barasi S, Roberts MHT (1977) Responses of motoneurones to electrophoretically applied dopamine. Br J Pharmacol 60:29-34.

Bekkers JM (1993) Enhancement by histamine of NMDA-mediated synaptic transmission in the hippocampus. Science 261:104-106.

Bourne HR, Nicoll R (1993) Molecular machines integrate coincident synaptic signals. Neuron [Suppl] 10:65-75.

Carp JS, Anderson RJ (1982) Dopamine receptor-mediated depression of spinal monosynaptic transmission. Brain Res 242:247-254.

Cepeda C, Buchwald NA, Levine MS (1993) Neuromodulatory actions of dopamine in the neostriatum are dependent upon the excitatory amino acid receptor subtypes activated. Proc Natl Sci USA 90:95769580.

Dudel J, Franke C, Hatt H (1990) Rapid activation, desensitization and resensitization of synaptic channels of crayfish after glutamate pulses. Biophys J 57:535-545.

Felder CC, Jose PA, Axelrod J (1989) The dopamine-1 agonist, SKF 82526 , stimulates phospholipase $\mathrm{C}$ activity independent of adenylate cyclase. J Pharmacol Exp Ther 248:171-175.

Glass DB, Lundquist LJ, Katz BM, Walsh DA (1989) Protein kinase inhibitor-(6-22)-amide peptide analogs with standard and nonstandard amino acid substitutions to phenylalanine 10: inhibition of cAMP-dependent protein kinase. J Biol Chem 264:14579-14584.
Greengard P, Jen J, Nairn AC, Stevens CF (1991) Enhancement of the glutamate response by cAMP-dependent protein kinase in hippocampal neurons. Science 253:1135-1138.

Jankowska E, Jukes MGM, Lund S, Lundberg A (1967) The effect of DOPA on the spinal cord. 5. Reciprocal organization of pathways transmitting excitatory action to alpha motoneurones of flexors and extensors. Acta Physiol Scand 70:369-388.

Kebabian JW, Greengard P (1971) Dopamine-sensitive adenyl cyclase: possible role in synaptic transmission. Science 174:1346-1349.

Kendall MG, Stuart A (1969) The advanced theory of statistics, 3d ed, vol 1, p 232. New York: Hafner.

Knapp AG, Schmidt KF, Dowling JE (1990) Dopamine modulates the kinetics of ion channels gated by excitatory amino acids in retinal horizontal cells. Proc Natl Acad Sci USA 87:767-771.

Liman ER, Knapp AG, Dowling JE (1989) Enhancement of kainategated currents in retinal horizontal cells by cyclic AMP-dependent protein kinase. Brain Res 481:399-402.

Maguire G, Werblin F (1994) Dopamine enhances a glutamate-gated ionic current in OFF bipolar cells of the tiger salamander retina. J Neurosci 14:6094-6106.

Mahan LC, Burch RM, Monsma FJ, Sibley DR (1990) Expression of striatal DI dopamine receptors coupled to inositol phosphate production and $\mathrm{Ca}^{2+}$ mobilization in Xenopus oocytes. Proc Natl Acad Sci USA 87:2196-2200.

O'Dowd BF (1993) Structures of dopamine receptors. J Neurochem 60:804-816

Pereda A, Triller A, Korn H, Faber DS (1992) Dopamine enhances both electrotonic coupling and chemical excitatory postsynaptic potentials at mixed synapses. Proc Natl Acad Sci USA 89:1208812092.

Pereda A, Nairn AC, Wolszon LR, Faber DS (1994) Postsynaptic modulation of synaptic efficacy at mixed synapses on the Mauthner cell. J Neurosci 14:3704-3712.

Raymond LA, Blackstone CD, Huganir RL (1993) Phosphorylation and modulation of recombinant GluR6 glutamate receptors by cAMPdependent protein kinase. Nature 361:637-641.

Ridet J-L, Sandillon F, Rajaofetra GM, Privat A (1992) Spinal dopaminergic system of the rat: light and electron microscopic study using an antiserum against dopamine, with particular emphasis on synaptic incidence. Brain Res 598:233-241.

Rosenheimer JL, Smith DO (1990) Age-related increase in soluble and cell surface-associated neurite-outgrowth factors from rat muscle. Brain Res 509:309-320. 
Schmidt K-F, Kruse M, Hatt H (1994) Dopamine alters glutamate receptor desensitization in retinal horizontal cells of the perch (Perca fluviatilis). Proc Natl Acad Sci USA 91:8288-8291.

Schnaar RL, Schaffner AE (1981) Separation of cell types from embryonic chicken and rat spinal cord: characterization of motoneuronenriched fractions. J Neurosci 1:204-217.

Smith DO, Hatt H (1993) Dopamine potentiates glutamate-activated currents in spinal motoneurons. Soc Neurosci Abstr 19:719.

Smith DO, Franke C, Rosenheimer JL, Zufall F, Hatt H (1991) Desensitization and resensitization rates of glutamate-activated channels may regulate motoneuron excitability. J Neurophysiol 66:1166-1175.

Surmeier DJ, Eberwine J, Wilson CJ, Cao Y, Stefani A, Kitai ST (1992) Dopamine receptor subtypes colocalize in rat striatonigral neurons. Proc Natl Acad Sci USA 89:10178-10182.

Temkin R, Lowe D, Jensen P, Smith DO (1993) Glutamate receptor transcription in embryonic spinal motoneurons. Soc Neurosci Abstr 19:926.

Wang L-Y, Salter MW, MacDonald JF (1991) Regulation of kainate receptors by cAMP-dependent protein kinase and phosphates. Science 253:1132-1135.

Wang L-Y, Taverna FA, Huang X-P, MacDonald JF, Hampson DR (1993) Phosphorylation and modulation of a kainate receptor (GluR6) by cAMP-dependent protein kinase. Science 259:11731175.

Weil-Fugazza J, Godefroy F (1993) Dorsal and ventral dopaminergic innervation of the spinal cord: functional implications. Brain Res Bull 30:319-324.

Zhou Q-Y, Grandby DK, Thambi L, Kushncr JA, Van Tol HHM, Cone R, Pribnow D, Salon J, Bunzow JR, Civelli O (1990) Cloning and expression of human and rat $D_{1}$ dopamine receptors. Nature 347:7680. 